\title{
Living knowledge of the healing plants: Ethno-phytotherapy in the Chepang communities from the Mid-Hills of Nepal
} Arun Rijal

Address: House no.2111 "Kha", Pasanglhamu Marg, Ward no 6 Bauddha, Mahankal, Kathmandu, Nepal

Email: Arun Rijal - arunrijal@yahoo.com

Published: 25 November 2008

Journal of Ethnobiology and Ethnomedicine 2008, 4:23 doi:10.1 186/I746-4269-4-23

This article is available from: http://www.ethnobiomed.com/content/4/I/23

(c) 2008 Rijal; licensee BioMed Central Ltd.

This is an Open Access article distributed under the terms of the Creative Commons Attribution License (http://creativecommons.org/licenses/by/2.0), which permits unrestricted use, distribution, and reproduction in any medium, provided the original work is properly cited.

Received: 13 May 2008

Accepted: 25 November 2008

\begin{abstract}
Contribution of indigenous knowledge in developing more effective drugs with minimum or no side effects helped to realise importance of study of indigenous remedies and the conservation of biological resources. This study analysed indigenous knowledge regarding medicinal plants use among the Chepang communities from ward number 3 and 4 of Shaktikhor Village Development Committee located in the central mid hills of Nepal. Data were collected in a one-year period and included interviews with traditional healers and elders. Chepangs are rich in knowledge regarding use of different plants and were using a total 219 plant parts from 115 species including one mushroom (belonging 55 families) for medicinal uses. Out of these, 75 species had 118 different new medicinal uses and 18 of them were not reported in any previous documents from Nepal as medicinal plants. Spiritual belief, economy and limitation of alternative health facilities were cause of continuity of people's dependency on traditional healers. Change in socio-economic activities not only threatened traditional knowledge but also resource base of the area. Enforcement of local institution in management of forest resources and legitimating traditional knowledge and practices could help to preserve indigenous knowledge.
\end{abstract}

\section{Background}

The close and traditional dependence of many indigenous and local communities on biological resources and its importance in conservation and development is now being recognised widely. The growing appreciation of the value of traditional knowledge is due to its importance to development, conservation and other wide range of uses also for other people than those who are traditionally dependent on it [1-4].

Traditional knowledge that built upon the long experiences of people was adopted in social, economic, environmental, spiritual and political practices. Since traditional knowledge is developed through a long trail and error, this could guide search for new drugs. Together with the recognition of importance of traditional knowledge, seri- ous concern about the loss of knowledge could be observed in last few years throughout the world $[4,5]$.

Chepangs lived a semi-nomadic life, more dependent on the forests. They have generated enormous knowledge on a large number of plants species on which they have depended for centuries. Due to this, forests were most important resources for them in terms of food, fibre, medicine, housing materials, fodder and various other needs $[6,7]$. The loss of knowledge could also threat the existing balance between these people and natural environment.

Despite many studies on various uses of plants a large number of plants and associated traditional uses still wait proper documentation [8]. This is perhaps because of the fact that these studies do not fully represent the wide 
range of environments in Nepal, where topography has created diverse ecological niches for species and stirred localized cultural constructions. In Chepang areas also documentation of ethonobotanical knowledge was limited to a few medicinal plants $[9,10]$. This study helped to document knowledge of several medicinal herbs use including many new reports for Nepal.

\section{Chepangs}

There are approximately 52,000 Chepangs in 2000 [11] and their habitats are quite identical and found along the Trisuli, Narayani and Rapti Rivers and in the major catchments of their tributaries covering the adjoining frontiers of Dhading, Makwanpur, Chitwan and Gorkha districts of central Nepal [12]. Being hunter-gatherers until about 80 years ago [6], the Chepang are considered among the most primitive indigenous peoples of Nepal. They practise shifting cultivation (Slash and burn cultivation) and the evidence suggests that they are highly forest-dependent $[6,10,12-14]$ as well as among the poorest in Nepal [12] and besides their own use of forest resources such as timber, herbs and wild food, they barter and some times sell forest products $[6,12]$. The forest is used as an important source of food, fibre, medicine, housing materials, fuel and fodder. They are generally considered to be shy and easily dominated by other ethnic groups [15], who have been migrating from the mountains to the lowlands for the last 40-50 years [6].

\section{Methodology \\ Study Area}

This study was conducted in two villages in ward no. 3 and 4 of Shaktikhor Village Development Committee (VDC) $\left(27^{\circ} 40^{\prime} \mathrm{E}-27^{\circ} 48^{\prime} \mathrm{E}\right.$ and $\left.84^{\circ} 35^{\prime} \mathrm{N}-84^{\circ} 39^{\prime} \mathrm{N}\right)$ of Chitwan District in the Central Nepal (Figure 1). Though these two areas belong to the same VDC, they are in different climatic zone and have different situation of access. The population distribution is also not homogeneous but dependency on forest is common in both areas. The distribution of Chepangs is similar in these two areas. The ward number 3 is accessible from road whereas ward number 4 is on the top of the hill at one day long walking distance with no road access. The Climatic zone includes Tropical to subtropical. The altitude of this village varies from $300 \mathrm{~m}$ to $2500 \mathrm{~m}$ asl. The vegetation of this area includes lowland Sal forest, hill Sal forest, Schima wallichi forest, tropical riverine forest, tropical mixed broadleaved forest and subtropical mixed forest.

\section{Methods}

Study took place between 1 June 2001 and 31 May 2002. Basically, semi-structured interviews were conducted with key informants like traditional healers for medicinal plants, and elder people and women for edible and other useful plants. Initial rapport-building visits included dis- cussions with local leaders, traditional healers and other key informants as well as community-wide meetings introducing the research activity and its purpose. This helped to identify key informants ( 2 traditional healers both man and 10 elders of which 4 female and 6 male all above 60 years old). The 'artefact/interview' approach [16] was also used, i.e. asking questions about the use of plants for different purposes and making forest visits to identify the plant species. During forest visits, queries were made on plants not mentioned in the interviews, to trap the knowledge of forgotten species. Since Chepangs are very shy, a trained local assistant was used to facilitate the interviews. In interview, information on use of various medicinal plants to cure different illness, plant part used, use methods and their faith on traditional healers were acquired. Interview was mainly in Nepali but when they find difficulties to explain or understand any thing then the local assistant helped to interpret. Few old Chepangs were not confident of Nepali language so interpreter helped to interpret question as well as answer. Preparation method of any medicinal herb varies for different illness and also seriousness of the illness. Moreover, traditional faith healers were reluctant to explain mode of preparation of herbs for serious illnesses to avoid potential casualties from inexperienced person. Therefore, mode of preparation is not included in this report. Plant parts having multiple use are counted for each use. Supply column in the [see additional file 1] indicates source of supply (i.e. from wild or from the garden). Author identified plants using his more than 20 years experience from botanical studies in different parts of Nepal. Herbarium specimens were prepared following standard botanical procedure for only new specimens or specimen that needed further confirmation. The confusing species were confirmed by tallying with the herbarium at the National Herbarium and Plant Research Department (Kath), Godawari, Nepal. Plant names follows Press et al. 2000 [17]. Secondary information involves publication on information of the study area, ethnobotanical studies of Chepangs, and medicinal plants studies in Nepal. To confirm new reports for Nepal, findings were compared with all published information from Nepal including bulletins of Department of Medicinal plants of Nepal.

A name list of permanent residents of ward no. 3 and 4 that was made available by Village Development Committee (VDC) was used to group them into sex and five age classes $(<20,21-30,31-40,41-50,>50 \mathrm{yrs})$ for each ward. From this list, 12 individuals were drawn randomly from each age class of both sex for each ward $(n=2 \times 5 \times$ $12 \times 2=240$ ) and interviewed for their knowledge of medicinal plant use. Total Chepang population in these two wards was 168 household i.e. 1008 individuals. The sample size represent $24 \%$ of the total Cheapang population. The knowledge difference between youth and elder 


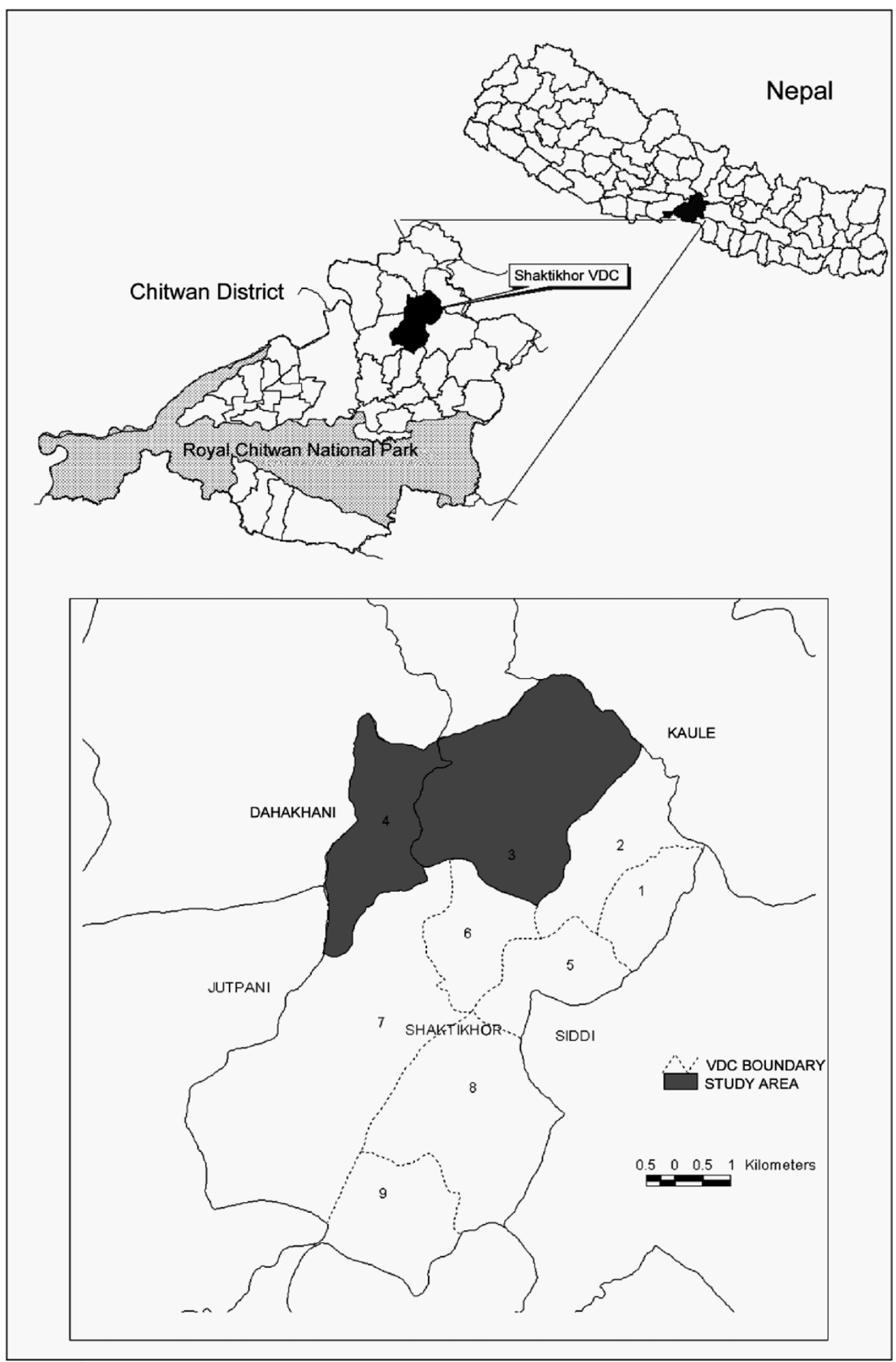

Figure I

Map showing study area. 
people and the transmission of knowledge was analysed through mixed linear regression analysis at 95\% confidence interval of knowledge for each age class, sex and ward. The use of $95 \%$ confidence interval is justified by there being a tradition that all age groups are involved in plant use and good sharing of knowledge. For several causes affecting knowledge, justifications were obtained from elder Chepangs and relevant secondary sources. Estimates from the statistical analysis of plant use knowledge for each sex of all age groups from both wards were plotted against the age groups to explain graphically the knowledge distribution among each sex from both wards for all age groups (Figure 2). Similarly, average plant use knowledge for each uses was calculated to see knowledge difference in each uses. Standard deviation of each uses for each sex was also calculated to analyse magnitude of differences within each sex of both wards (Table 1 \&2).

\section{Results}

\section{Plant Use}

A total 219 plant parts from 115 species (belonging 55 families) including one mushroom were in use among Chepang for medicinal uses. Of them 29 are trees, 36 shrubs, 25 herbs, 21 climbers, 3 ferns and one fungi (mushroom). These belong to 105 genera and 55 families. Of the plants in use among Chepangs, 75 species had 118 different new medicinal uses for Nepal and 18 of them were not reported in any previous documents from Nepal as medicinal plants. Number of plant used to treat fever was highest (17 species) followed by wound, diarrhoea and indigestion (14 to each). Of these 115 species, 107 are wild, 7 cultivated and 1 both wild as well as cultivated. Responding question regarding faith on traditional healers, all respondent (except few youth) expressed their faith.

Plant parts use indicated that the root/rhizome had the highest use (45) followed by bark (39), fruit (32) and leaf (32) (Table 3). In some plants more than one part are used to cure various illnesses. Of these, 7 species were found cultivated, 107 species were collected from the wild and 1 species was found both in wild as well as planted. Detail results with species name, local name, part(s) used, ailments treated are tabulated [see additional file 1]. To maintain regeneration, traditional harvest practice was

Table I: Average medicinal plant use knowledge among male and female of ward number $3 \& 4$ of Shaktikhor VDC.

\begin{tabular}{lll}
\hline Ward & Sex & Medicine \\
\hline 3 & M & $130.9 \pm(64.7)$ \\
3 & F & $96.6 \pm(63.6)$ \\
4 & M & $111 \pm(59.1)$ \\
4 & F & $117.2 \pm(66.6)$ \\
\hline
\end{tabular}

The values in the parenthesis are standard deviation. found leaving some flowers for seed formation, whole aerial part collection of annuals only after dispersal of seed and leaving some roots or tubers or bulbs for regeneration.

Of the 115 medicinal use species, 9 belong to different IUCN threat categories (Table 4). These falls within four threat categories and altogether 13 different parts of these species were in use among Chepang communities. Of the 9 threatened species, 4 are tree, 2 shrub, 2 climber and 1 herb.

Species use and plant part use indicated that there were many species for common illnesses like Indigestion (18 species), Fever (17 species) and wound (15 species) (Table 5).

\section{Knowledge distribution}

Model of all ages of both sexes from two wards:

$$
\mathrm{Y}_{\mathrm{i}}=\mu_{0}+\alpha \cdot \operatorname{age}_{\mathrm{j}}+\beta \cdot \operatorname{sex}_{\mathrm{k}}+\gamma \cdot \operatorname{sex}_{\mathrm{k}}\left(\operatorname{ward}_{\mathrm{l}}\right)+\varepsilon_{\mathrm{i}}
$$

Where $\mathrm{i}=1 \ldots \ldots .240 ; \mathrm{j}=1 \ldots \ldots .54, \mathrm{k}=1,2, \mathrm{l}=1,2, \mathrm{Y}=$ medicinal plant use knowledge (number); $\mu_{0}, \alpha_{\text {age( }(\mathrm{j})}, \beta_{\text {sex }(\mathrm{k})}$ and $\gamma_{\text {sexl(wardk) }}$ are model parameters and $\varepsilon_{\mathrm{i}}$ is the residual term $\left(\varepsilon_{\mathrm{i}} \sim \mathrm{N}\left(0, \sigma^{2}\right)\right)$.

Statistical analysis model indicated that age, sex and interaction of sex and ward has significant effect on knowledge regarding medicinal plants.

Figure 2 (also Table 1 and 2) shows that men of Ward no. 3 are the comparatively most knowledgeable over the entire age spectrum, while men of Ward no. 4 are the least knowledgeable below 40 years of age. In Ward no. 4, women are generally slightly more knowledgeable than men (Table 2). In Ward no. 3, the knowledge difference between men and women increases with age whereas it decreases in Ward no. 4.

\section{Discussion}

\section{Herbal Knowledge}

Compare to other ethnic groups of Nepal, Chepangs of Shaktikhor were found very knowledgeable in use of plant for various need of livelihood [9,18-26]. This indicates close affinity of these people with plants of the area. The number of plant in use (115 species) was found higher compared to the reports from different ethnic groups of Nepal except the Tharu communities of Chitwan District [17]. From the use diversity aspects, it is highest (219) then earlier highest use (185) among Tharus of Chitwan [ibid.]. Although Khan, 1998 [9] also studied these communities, he was able to report only 19 medicinal plants in use but realised limitation of his study (only one day fieldwork) and suggested for more in-depth study. No 
Table 2: Models describing variation in plant use knowledge.

Model describing the variation of medicinal plant use knowledge among different age groups, sex and wards (LS Means). $\mathbf{N}=\mathbf{2 4 0}, \sigma^{2}=493.8 \mathrm{I}, \sigma$ $=22.22, \mathrm{df}=106$

\begin{tabular}{llll}
\hline Effect & Estimate & Standard Error & $\operatorname{Pr}>|\mathbf{t}|$ \\
\hline Intercept & 185.6 & 48.21 & $<0.0002$ \\
Age & 6.9479 & 0.3765 & $<0.0001$ \\
Sex F & 105.75 & 2.7610 & 0.0001 \\
Sex M & 122.08 & 2.7611 & 0.0001 \\
Ward 3 & 113.66 & 2.7615 & 0.0001 \\
Ward 4 & 114.17 & 2.7606 & 0.0001 \\
Sex F*Ward 3 & -37.55 & 9.259 & 0.0001 \\
Sex M*Ward 3 & 0 &. &. \\
Sex F*Ward 4 & 0 & $\cdot$ &. \\
Sex M*Ward 4 & 0 & $\cdot$ & $\cdot$ \\
\hline
\end{tabular}

new medicinal use for Nepal was reported in earlier studies of Chepangs $[9,10]$. Therefore, this study has contributed to bring more information on traditional medicinal plant use knowledge with the record of 120 new medicinal uses of 75 different species of which 18 species were not reported in any previous documents from Nepal as medicinal plants $[9,10,19,25,27-33]$,$] .$

\section{Dependency}

Like in many other rural communities $[6,7,34]$, their faith was reason for continuing herbal treatment. Chepangs belief that holy spirits live in plants, animals, rivers and mountains. According to their beliefs, disease and natural disasters are caused by disrespect of the spirits [7]. Due to such belief they have faith on Pande or Phal or Janne (traditional faith healers) and for preference to go to them to

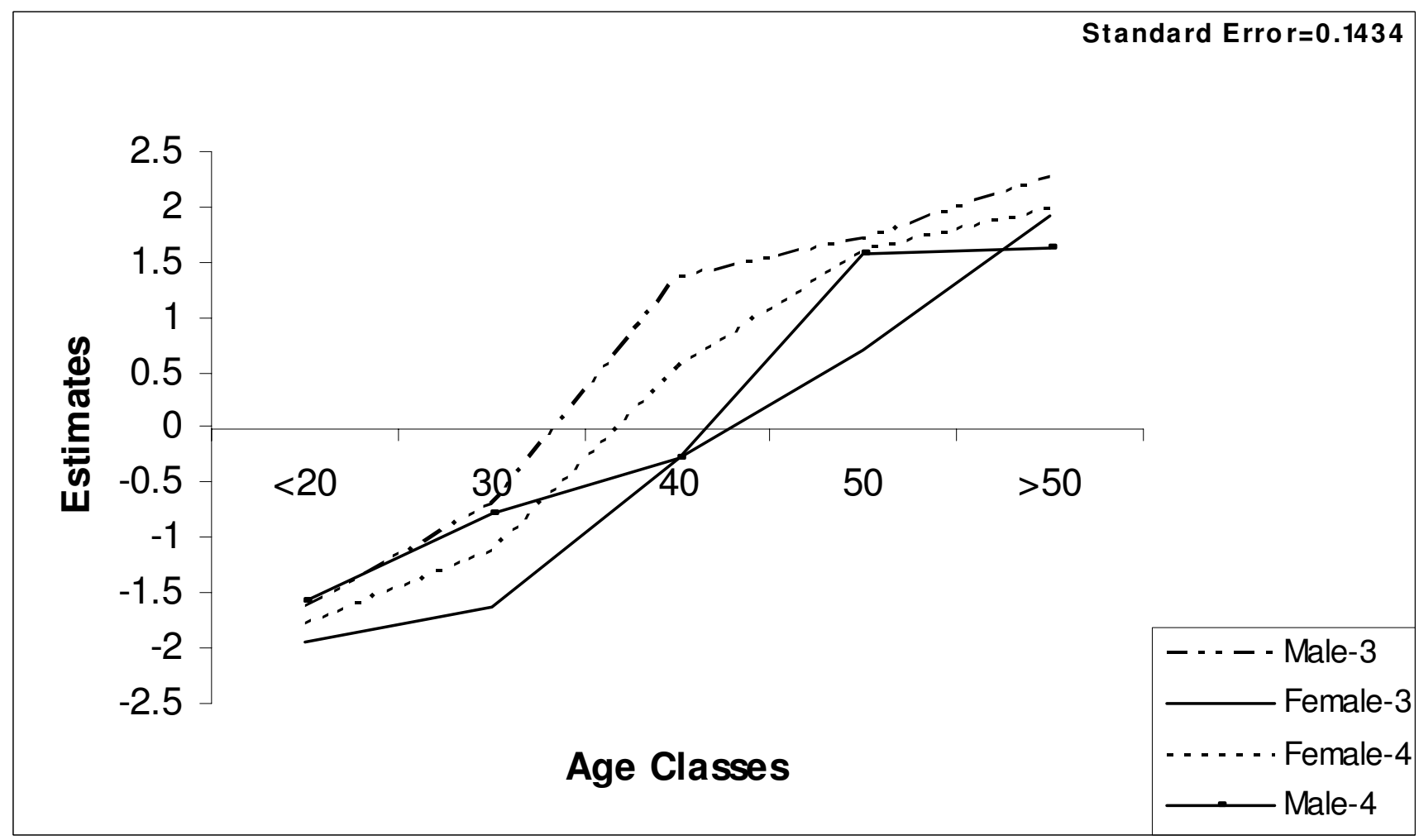

\section{Figure 2}

Knowledge estimates for different age and sex groups from the two wards. 
Table 3: Plant parts use.

\begin{tabular}{ll}
\hline Plant part & No. of uses \\
\hline Bark & 38 \\
Root/rhizome & 45 \\
Tuber/bulb & 10 \\
Flower/inflorescence & 2 \\
Fruit & 32 \\
Seed/Grain & 9 \\
Oil/Butter & 1 \\
Latex/sap & 11 \\
Leaf & 33 \\
Stem/Stem fibre & 17 \\
Tender shoot & 20 \\
Whole plant & 1 \\
\hline Total parts used & 219 \\
\hline
\end{tabular}

treat illness through spiritual practices. Besides, accessibility and economic reasons had also forced them to depend on traditional healing practice. The health post with only health assistant was established in this area very recently and is far from the village. The health post receives very limited medicine from the government and mainly for common diseases or wounds. Since most of the Chepangs were familiar with herbs of common remedies (fever, cough, cold, headache, stomach ache, body pain, heat sickness, constipation, internal heat sensation, weakness, indigestion, sprain, anti-helmintic, scabies, psynocytis, herpes zoster, burn, teeth infection, vomiting and dealcoholisation, minor diarrhoea/dysentery) they rather prefer to use herbs then visiting health post. In some serious cases of the illness like diarrhoea/dysentery, sprain, psynocysis, burn or vomiting, and other special cases like snake bite, scorpion sting, fracture, pneumonia, liver/ heart/lung/kidney problems, typhoid, taenia pedis, malnourishment, urine or other infection, malaria, abortion, inflammation, miscarriage and cholera they visit traditional faith healer (Pande/Pha//Janne). The plant parts and species use (Table 5) also indicated high number of species and plant parts use for remedy of common illnesses. They visit health posts only if the Pande/Pha//Janne advice in serious cases but they usually don't get much help as health post doesn't have doctor but only health assistant. As mentioned by Gurung, 1995 [7], villagers of this area also informed that there had been several cases in which people returned to the traditional healers when illness was not cured by modern medicine. The limited medical services in health post, poor economy and belief in faith on traditional healers are the cause of returning to traditional healers. Moreover, traditional practice was cheaper as payment could be made with goods like chicken or/and food grains which are available at their home.

\section{Conservation and plant use}

The plant part use examination showed that root/rhizome is used in a large number of species followed by bark use. Root/rhizome and stem collection if not done carefully then could threaten existence of the species [35]. Debarking or collection of sap/latex could threat the tree if practiced inappropriately. Even more sensitive is the collection of root, rhizome, tuber and bulb. It is learned from the local residents that a large number of medicinal species are collected from these areas for commercial purpose and whole plant harvest makes the largest volume followed by seed, fruit, stem and tuber. The threat is more serious to the 9 IUCN listed species, of which root/rhizome/tuber is collected of 4 , followed by stem and bark both of 2 (Table 4). These threatened species besides

Table 4: Threatened species in use.

\begin{tabular}{|c|c|c|c|c|c|c|}
\hline Species & Habit & $\begin{array}{l}\text { IUCN Threat } \\
\text { category }\end{array}$ & Plant Part Used & Medicinal uses & Other uses* & Total number of uses \\
\hline Acacia catechu (L.f.) Willd. & Tree & CT & Stem, bark & 2 & 2 & 4 \\
\hline Alstonia scholaris (L.) R.Br. & Tree & $\mathrm{R}$ & Latex, stem & 1 & I & 2 \\
\hline $\begin{array}{l}\text { Bergenia ciliata (Haw.) } \\
\text { Sternb. }\end{array}$ & Herb & CT & Rhizome & 4 & I & 5 \\
\hline $\begin{array}{l}\text { Crateva unilocularis Buch.- } \\
\text { Ham. }\end{array}$ & Tree & $\mathrm{R}$ & Bark, shoot & 1 & 2 & 3 \\
\hline $\begin{array}{l}\text { Dioscorea deltoidea Wall. } \\
\text { Ex Griseb }\end{array}$ & Climber & $\mathrm{CT}$ & Tuber & 1 & 2 & 3 \\
\hline $\begin{array}{l}\text { Dioscorea prazeri Prain \& } \\
\text { Burkill }\end{array}$ & Climber & CT & Tuber & 1 & 2 & 3 \\
\hline $\begin{array}{l}\text { Oroxylum indicum (L.) } \\
\text { Kurz. }\end{array}$ & Tree & $\mathrm{V}$ & Seed & 1 & 0 & I \\
\hline $\begin{array}{l}\text { Rauvolfia serpentina (L.) } \\
\text { Benth. ex Kurz }\end{array}$ & Shrub & E & Root, leaf & 2 & I & 3 \\
\hline $\begin{array}{l}\text { Swertia chirayita (Roxb.ex } \\
\text { Fleming) H. Karst. }\end{array}$ & Shrub & $\mathrm{V}$ & Whole plant & 1 & 1 & 2 \\
\hline
\end{tabular}

*Other uses include uses other than medicinal (source: Rijal, 2007).

$\mathrm{CT}=$ Commercially Threatened, $\mathrm{R}=$ Rare, $\mathrm{V}=$ Vulnerable, $\mathrm{E}=$ Endangered. 
Table 5: Number of plants for each illness.

\begin{tabular}{|c|c|c|}
\hline Illness & Plant parts in used & Number of plant used \\
\hline Abdominal spasm & 9 & 9 \\
\hline Abortion & I & I \\
\hline Antihelmintic & 13 & 13 \\
\hline Asthama & 2 & 2 \\
\hline Body ache & 2 & 2 \\
\hline Boils & 1 & I \\
\hline Burn & 4 & 4 \\
\hline Chest pain & 3 & 3 \\
\hline Cholera & 2 & 2 \\
\hline Cold & 8 & 8 \\
\hline Constipation & 3 & 3 \\
\hline Cough & 11 & 11 \\
\hline Cuts & 2 & 2 \\
\hline Dealcoholisation & I & I \\
\hline Diarrhoea & 15 & 12 \\
\hline Dysentery & 13 & 13 \\
\hline Enuresis & 1 & I \\
\hline Fever & 17 & 17 \\
\hline Fracture & 7 & 6 \\
\hline Gastric & I & I \\
\hline Heart pain & I & I \\
\hline Heat sickness & 11 & 11 \\
\hline Herpes zoster & 1 & I \\
\hline Indigestion & 18 & 18 \\
\hline Inflamation & $\mathrm{I}$ & 1 \\
\hline Insecticide & 4 & 4 \\
\hline Internal heat sickness & I & I \\
\hline Liver problem & I & I \\
\hline Loss of weight & 3 & 3 \\
\hline Malaria & I & I \\
\hline Malnourishment & 2 & 2 \\
\hline Menopause & I & I \\
\hline Miscariage & I & I \\
\hline Oedema & i & I \\
\hline Pneumonia & 2 & 2 \\
\hline Psynocytis & 3 & 3 \\
\hline Snake bite & 5 & 5 \\
\hline Sprain & 2 & 2 \\
\hline Scabies & 1 & I \\
\hline Scorpion sting & 2 & 2 \\
\hline Stomachic & 6 & 6 \\
\hline Taenia pedis & 2 & 2 \\
\hline Teeth infection & 4 & 4 \\
\hline Throat problem & I & I \\
\hline Tonic & 6 & 6 \\
\hline Typhoid & 3 & 3 \\
\hline Urine infection & 2 & 2 \\
\hline Vomiting & 2 & 2 \\
\hline Wound & 15 & 15 \\
\hline Total & 219 & $215 *$ \\
\hline
\end{tabular}

*Since several species have multiple uses, total count counted species more than once (for each remedy) and due to that total became 215 which in reality is only 115 species.

medicinal use also have several other uses including trade [36]. It is frequently claimed that commercial utilisation of non-cultivated plant species in Nepal is unsustainable; although the scientific evidence found very weak empirical support for this [37]. The traditional practice of Chepangs paid adequate attention to avoiding destructive 
harvesting [7]. They used to leave some roots, tubers or bulbs for regeneration purposes but elder Chepangs said the high market demand and loss of customary rights induced uncontrolled harvest of open-access resources. Market driven problems like premature collection and unsustainable harvest induced by unhealthy competition from migrated people and increased collectors from neighbouring areas could affect resource base of this area. Unhealthy competition seems to be increased by market force and that could lead to extinction of species and when plant will be out of people's context the knowledge related to that will also disappears [38]. Therefore, to protect species and their use knowledge it is important to control reckless harvest and this is only possible by enforcement of local social control mechanism. Besides, recognition of traditional knowledge by legitimising it to secure benefits related to it will encourage indigenous people to maintain traditional practices and protect natural resources.

\section{Knowledge distribution}

Several studies from all over the world indicate that elder people know more about plant use than younger [39-43] and this corresponds to the findings of the present study (Table 2, and Figure 2). In Chepang communities also wild medicinal plants remain part of old people's context: they continue collection and preparation for utilisation.

Difference in knowledge between young and old people would be expected whereas significant difference between two adjacent age classes indicates problem of knowledge transmission. Loss of species, change in social practices, influence of migrated culture, influence of market, influence of development activities, change in life style, and policy problems are some of the important factors that potentially affect knowledge transmission [5,44-46]. Knowledge generated by elders from historic practices [47-49] and transmitted vertically to the younger generation is very much related to the affinity between family members [50-52]. Traditionally, all members of a Chepang family used to gather around the fireplace in the morning and evening, where sharing of knowledge of various things including plant use took place. Multi-generational families provided ample opportunities for sharing indigenous knowledge [53] and changes of such social structures affected knowledge transmission [54]. Moreover, some of the species seems to be extinct locally and this might have affected knowledge in young people.

Knowledge is generated from observation and implementation, i.e. learning by doing. Women in rural societies worldwide are often primarily responsible for ensuring household food security, health and family continuity $[38,55]$ and due to that women are expected to be more rich than men in indigenous plant use knowledge $[41,56-$
58]. However, medicinal plant knowledge analysis indicated that medicinal plant use knowledge specifically the one used to cure illness of serious nature was limited to traditional healers only. Moreover, there is clear evidence that in the homogeneous ward, men are in general more knowledgeable than women while women were more knowledgeable than men in heterogeneous ward (Figure 2 , Table 1 \&2). The reason for men being more knowledgeable then women in homogeneous ward (ward no. 3) is due to big difference in knowledge about medicinal plant use (Table 1), and one of the reason for this difference could be because all shaman-healers are men and do the 'serious' medicinal plant collection [7], while women concentrate on plants used for common and minor illnesses.

Men were more knowledgeable in the homogeneous community (Ward no. 3) than in heterogeneous community (ward 4) (Table 1 \&2, Figure 2) also indicates erosion of indigenous knowledge due to socio-economic influences. In Ward no. 4, Chepangs' lifestyle is socially and economically influenced by the in-migrated nonChepangs [6,7] and Stamm et al., 2004 [59] hold that the influence of an introduced culture results in loss of knowledge. More than half of the population of Ward no. 4 is non-Chepang $[6,11]$. Moreover, changes in life style and socio-economic status of people are reflected in a declining use of wild plants [43] which ultimately affects the knowledge transfer $[60,61]$. The influence of nonChepangs on the life style of Chepangs was observed most outspoken among the younger generation. Devaluation of traditional plant use practices by non-Chepangs has developed a prestige feeling among them, making the young Chepangs embarrassed at collecting wild plant products and follow traditional practices in general, which resulted in loss of collection skills (e.g. tuber and root digging) and use knowledge [7]. Some Chepangs have married non-Chepangs and due to that changed life style and cultural practices, and the interaction between children of the two groups has also changed the cultural and social understanding of Chepang children [7]. Moreover, like in other aboriginal populations [62] Christian missionaries made several young Chepangs stop practising traditional spiritual and cultural activities, including herbal treatment from Pande (healer) [7] and nonChepangs encouraged them to use modern medicine, leading to a loss of indigenous knowledge of medicinal plants.

\section{Conclusion}

Chepang's knowledge could be useful for research as well as development activities. To protect the knowledge of traditional plant use and the benefits derived from it, the state should acknowledge folklore and legitimise its role. Species that are in traditional herbal practice should be 
protected because rural communities depend on them. By supporting traditional management institutions, traditional harvest practice should be encouraged to make harvest sustainable and benefit rural communities.

\section{Competing interests}

The author declares that they have no competing interests.

\section{Authors' contributions}

AR carried out field research, statistical analysis of the data and write up of the manuscript.

\section{Additional material}

\section{Additional file 1}

Medicinal plants and their uses. The table lists different medicinal plants with their local names, habit, part used and medicinal uses.

Click here for file

[http://www.biomedcentral.com/content/supplementary/17464269-4-23-S1.doc]

\section{Acknowledgements}

I would like to thank Chepang people of Shaktikhor Village Development Committee for sharing their knowledge. I also like to thank Mr. Tilak Gurung and Ram Gurung for their assistance in the filed works. Russel E. Train Fellowship for Nature provided financial assistance to carryout this study.

\section{References}

I. Benz B, Cevallos J, Munoz E, Santana F: Ethnobotany serving society: a case study from the Sierra de Manantlan Biosphere Reserve. Sida 1996, 17:1-16.

2. Convention on Biological Diversity (CBD): Traditional Knowledge and the Convention on Biological Diversity. 1992 [http:// www.cbd.int/traditional/].

3. Gerritsen PRW: Community development, natural resource management and biodiversity conservation in the Sierra de Manantlan biosphere reserve, Mexico. Community Development Journal 1998, 33:3|4-324.

4. Twang S, Kapoor P: Protecting and Promoting Traditional Knowledge: Systems, National Experiences and International Dimensions. In United Nations Conference on Trade and Development (UNCTAD) United Nations, New York and Geneva; 2004.

5. Brockman A, Masuzumi B, Augustine S: When all people have the same story, human will Cease to Exist, Protecting and Conserving Traditional Knowledge. A Report for the Biodiversity Conservation Office, Dene Cultural Institute 1997.

6. Chhetri NS, Ghimire S, Gribnau C, Pradhan S, Rana S: Can Orange Trees Bloom on a Barren Land. In Identification of development potentials of Praja communities in Chitwan District SNV, Kathmandu; 1997.

7. Gurung GM: Report from a Chepang Village (Society, Culture and Ecology). Kathmandu, Nepal; 1995.

8. Chaudhary RP: Biodiversity in Nepal - Status and Conservation. Craftsman Press, Bangkok, Thailand; 1998

9. Khan $\mathrm{MH}$ : Documentation of indigenous knowledge in the Chepang community of Shakti Khor VDC, Chitwan. In Ethnobotany for conservation and community development Edited by: Shrestha KK, Jha PK, Shengji P, Rastogi A, Rajbhandary S, Joshi M. Ethnobotanical Society of Nepal, Kathmandu; 1998:96-10I.

10. Manandhar NP: Medicinal Plants used by Chepang tribes of Makwanpur District, Nepal. Fitoterapia Lx (I), Perish 1989.

II. CBS: Population Census. In Central Bureau of Statistics HMG. Kathmandu; 200I.
12. Bhattrai TR: Chepang: Status, Efforts and Issues: A Syo's perspective. In Chepang Resources and Development Edited by: Bhattarai TR. SNV/SEACOW, Kathmandu; 1995.

13. Gautam MK, Roberts EH, Singh BK: Community based leasehold approach and agroforestry technology for restoring degraded hill forests and improving rural livelihoods in Nepal. Paper presented at the International Conference on Rural Livelihoods, Forests and Biodiversity, Bonn . 19-23 May 2003.

14. Pandit $\mathrm{BH}$ : Non-timber forest products on shifting cultivation plots (khorya): a means of improving livelihood of Chepang Rural Hill Tribe of Nepal. Asia-Pacific Journal of Rural Development 2001, II:I-14.

15. Bista DB: People of Nepal. Ratna Pustak Bhandar, Kathmandu 2004.

16. Martin GJ: Ethnobotany: A Method Manual. In A People and Plant Conservation Manual Chapman and Hall, London; 1995.

17. Press JR, Shrestha KK, Suttan DA: Annotated Checklist of the Flowering Plants of Nepal. The Natural History Museum, London 2000.

18. Coburn B: Some native medicinal plants of western Gurung. Kailash 1984, I I:55-88.

19. Manandhar NP: Medicinal plants of Nepal Himalaya. Ratna Pustak Bhandar, Kathmandu; 1980

20. Manandhar NP. Ethnobotanical notes on certain medicinal plants used by Tharus of Dangdeokhuri district, Nepal. International Journal of Crude Drug Research 1985, 23(4): I53-159.

21. Manandhar NP: A contribution to the ethnobotany of Mooshar tribes of Dhanusah district, Nepal. Journal of Natural History Museum, Kathmandu 1986, 10:53-64.

22. Manandhar NP: Traditional phytotherapy of Danuwar tribe of Kamlakhonj in Sindhuli district, Nepal. Fitoterapia 1990, 6I(4):325-332.

23. Manandhar NP: Medicinal plant-lore of Tamang tribes of Kabhrepalanchok district, Nepal. Economic Botany I991, 45(I):58-7I.

24. Manandhar NP: Native phytotherapy among Raute tribes of Dadeldhura district, Nepal. J Ethnopharmacol 1998, 60(3):199-206.

25. Manandhar NP: Plants and People of Nepal. Timber Press, Portland, Oregon, USA; 2002.

26. Sacherer J: The high altitude ethnobotany of Rolwaling Sherpa. Contribution to Nepalese Studies 1979, 6(2):45-64.

27. Bhatta DD: Natural History and Economic Botany of Nepal. Orient Longman, New Delhi; 1977.

28. HMG: Medicinal Plants of Nepal for Ayurvedic Drugs. In Bulletin of Department of Medicinal Plants No. 15 Department of Plant Resources, Thapathali, Kathmandu, Nepal; 1995.

29. HMG: Medicinal Plants of Nepal. In Bulletin of Department of Medicinal Plants No.10 Department of Plant Resources, Thapathali, Kathmandu, Nepal; 1997.

30. HMG: Medicinal Plants of Nepal. In Bulletin of the Department of Medicinal Plants No.3 Department of Plant Resources, Thapathali, Kathmandu, Nepal; 2001.

31. Manandhar NP: An ethnobotanical study of Nuwakot. In Proceedings of First National Science and Technology Congress National Council for Science and Technology, Kirtipur, Kathmandu; 1982:72-79.

32. Pandey BD: The wealth of medicinal plants of Nepal. Proceeding of Peking Symposium, China 1964:183-140.

33. Shrestha TB: Traditional medicine and native plants of Nepal. Proceedings of the Seminar on Traditional Medicines and Role of medicinal Plants. Kathmandu. August 2-3, 1979.

34. Rijal A: Ethnobotany of Padampur: Analysis of Dependency and Conflict. In MSc Thesis The Agricultural University of Norway, Aas, Norway; 1994

35. Carvalho AR: Popular use, Chemical composition and trade of cerrado's medicinal plants (Goias's, Brazil). Environment, Development and sustainability 2004, 6:307-316.

36. Rijal A: Multifaceted Forest Management for Biodiversity Conservation and Poverty Alleviation: A Case Study of Mid Hills of Nepal. In Ph.D Thesis The University of Copenhagen, Copenhagen, Denmark; 2007.

37. Larsen HO, Olsen CS: Unsustainable collection and unfair trade? Uncovering and assessing assumptions regarding central Himalayan medicinal plant conservation. Biodiversity and Conservation 2007, 16:1679-1697. 
38. Saul R: Indigenous Forest Knowledge: Factors Influencing its Social Distribution. In Anthropology of Nepal: People, Problems and Processes Edited by: Allen M. Mandala Book Point, Kathmandu; 1992.

39. Benz B, Cevallos J, Santana F, Graf S: Loosing knowledge about plant use in the Sierra de Manantlan Biosphere Reserve, Mexico. Economic Botany 2000, 54:|83-191.

40. Caniago I, Siebert S: Medicinal plant ecology, knowledge, and conservation in Kalimantan, Indonesia. Economic Botany 1998, 52:229-250.

4l. Stark LL: Elderly people in modern society. Helium 2008 [http:/ /www.helium.com/items/233/43-elderly-people-in-modern-society].

42. Tsuij LJS: Loss of Cree traditional ecological knowledge in the Western James Bay region of Northern Ontario, Canada: A case study of the sharp-tailed grouse, Tympanuchus phasianellus phasianellus. The Canadian Journal of Native Studies 1996, 16:283-292.

43. Uniyal SK, Awasthi A, Rawat G: Developmental Processes, Changing Lifestyle and Traditional Wisdom: Analysis from Western Himalaya. The Environment 2003, 23:307-3 I2.

44. Oviedo G, Gonzales A, Maffi L: The Importance of Traditional Ecological Knowledge and Ways to Protect it. In Protecting and Promoting Traditional Knowledge: Systems, National Experiences and International Dimensions Edited by: Twang S, Kapoor P. United Nations Conference on Trade and Development (UNCTAD), United Nations, New York and Geneva; 2004.

45. Ruddle K: The Transmission of Traditional Ecological Knowledge. In Traditonal Ecological Knowledge, Concept and Cases Edited by: Inglis JT. International Program on Traditional Ecological Knowledge and International Development Research Centre, Ottawa, Canada; 1993:17-31.

46. Twarog S: Preserving, Protecting and Promoting Traditional Knowledge: National Actions and International Dimensions. In Protecting and Promoting Traditional Knowledge: Systems, National Experiences and International Dimensions Edited by: Twang S, Kapoor P. United Nations Conference on Trade and Development (UNCTAD), United Nations, New York and Geneva; 2004.

47. Alves RRN, Rosa IL: Why study the use of animal products in traditional medicines? Journal of Ethnobiology and Ethnomedicine 2005, I:5 [http://www.ethnobiomed.com/content/I/I/5].

48. Kurien J: Traditional ecological knowledge and ecosystem sustainability: new meaning to Asian coastal proverbs. Ecological Applications 1998, 8(1):S2-S5.

49. Schultes RE: Reasons for ethnobotanical conservation. In Traditional Ecological Knowledge: a collection of essays Edited by: Johannes RE. IUCN Publications Services.

50. Boesch C, Tomasello M: Chimpanzee and human cultures. Current Anthropology 1998, 39:59|-614.

51. Ladio AH, Lozada M: Non-timber forest product use in two human populations from NW Patagonia: a quantitative approach. Human Ecology 200I, 29:367-380.

52. Ulluwishewa R: Indigenous pest control methods in Sri Lanka. Honey Bee 1993, 4(I):3-4.

53. Hill F: Passing on Traditional Knowledge. In Indigenous Knowledge Conference Proceedings, Pennsylvania State University University Park, PA; 2004.

54. Wavey R: International workshop on knowledge and community-based resource management. Keynote Address. In Traditional Ecological Knowledge: Concepts and Cases Edited by: Inglis JT. Canadian Museum of Nature, Ottawa, Ontario; 1993.

55. Howard-Borjas P: Some implications of gender relations for plant genetic resources management. Biotechnology and Development Monitor 1999, 37:2-5.

56. Anguilar L, Blanco M, Juniga P: Protected Areas, Gender Makes the Difference. IUCN 2004 [http://www.frameweb.org/adl/en-US/ 2337/file/234/WCC Gender Fact Sheet on Protected Areas.pdf].

57. Voeks RA, Leony A: Forgetting the forest: Assessing medicinal plant erosion in eastern Brazil. Economic Botany 2004, 58:294-306.

58. Wayland P: Gendering local knowledge: medicinal plant use and primary health care in the Amazon. Medicinal Anthropology 200I, I5:17I-88.

59. Stamm BH, Stamm HE, Hudnall AC, Higson-Smith C: Considering A Theory of Cultural Trauma and Loss. Journal of Loss and Trauma 2004, 9:89-III.
60. Ladio AH, Lozada M: Edible wild plant use in a Mapuche community of north-western Patagonia. Human Ecology 2000, 28:53-71.

61. Ladio AH, Lozada M: Patterns of use and knowledge of wild edible plants in distinct ecological environments: a case study of a Mapuche community from north-western Patagonia. Biodiversity and Conservation 2004, 13:1 153-I I73.

62. Hill DM: Traditional medicine in contemporary contexts, protecting and respecting indigenous knowledge and medicine. 2003 [http://www.naho.ca/english/pdf/research tradition.pdf] National Aboriginal Health organisation (NAHO)
Publish with Biomed Central and every scientist can read your work free of charge

"BioMed Central will be the most significant development for disseminating the results of biomedical research in our lifetime. "

Sir Paul Nurse, Cancer Research UK

Your research papers will be:

- available free of charge to the entire biomedical community

- peer reviewed and published immediately upon acceptance

- cited in PubMed and archived on PubMed Central

- yours - you keep the copyright 